\title{
Alopecia Totalis in a Five-Year-Old Boy: A Case Report
}

\author{
Harapan Parlindungan Ringoringo* (i) \\ Edited by: Igor Spiroski \\ Citation: Ringoringo HP. Alopecia Totalis in a Five-Year- \\ Old Boy: A Case Report. Open Access Maced J Med Sci. \\ https://doi.org/10.3889/oamims 2022 (C) 407 \\ Keywords: Alopecia totalis; Child; Idiopathic; Minoxidi \\ Keywords: Alopecia totalis; Child; Idiopathic; Minoxid \\ *Correspondence: Dr. Harapan Parlindungan Rigoringo, \\ Department of Child Health, Faculty of Medicine, Lambung \\ Mangkurat University - RSD Idaman Banjarbaru, \\ E-mail: parlinringoringo@ulm.ac.id \\ Received: 25-Nov-202 \\ Revised: 21-Jan-2022 \\ Copyright: $\odot 2022$ Harapan Parlindungan Ringoring \\ Funding: This research did not receive any financia \\ Competing Interests: The authors have declared that no \\ competing interests \\ Open Access: This is an open-access article distribute \\ under the terms of the Creative Commons Attribution-
}

Department of Child Health, Faculty of Medicine, Lambung Mangkurat University, RSD Idaman Banjarbaru, Banjarbaru, Indonesia

\begin{abstract}
BACKGROUND: Alopecia totalis (AT) represent the severe form of alopecia areata with a worse prognosis. In the population, the prevalence of AT is $0.08 \%$. This study shows that prosential, minoxidil $2 \%$, and clobetasol propionate $0.05 \%$ could be considered hair loss treatment.

CASE PRESENTATION: A 5-year-old boy weighing $13.4 \mathrm{~kg}$ came to the hospital complaining of hair loss all over his head, bald since 2 months before. The eyebrows, eyelashes, and nose hairs were also missing. The diagnosis is AT. The patient was given Prosential therapy for 4 months. After 2 months of treatment, hair started to grow slightly, evenly across the head, eyebrows, and eyelashes. After that, the patient was lost contact. Four months later, the patient returned with hair loss complaints again. The patient's vital signs are normal. Eyes, ENT, heart lungs, abdomen: normal. Skin: no hair. Laboratorium: $\mathrm{Hb} 12.1 \mathrm{~g} / \mathrm{dL}$, hypereosinophilia. Feces and urine analysis were normal. Kidney and liver function were normal. Thyroid function: FT4: $1.1 \mathrm{ng} / \mathrm{dL}$, TsHs $0.916 \mathrm{ulU} / \mathrm{mL}$. The ANA test was negative. Diagnosis: Idiopathic AT with hypereosinophilia. The therapy was prosential, minoxidil $2 \%$, and clobetasol propionate $0.05 \%$
\end{abstract}

CONCLUSION: The etiology of AT should be sought in as much detail as possible because alopecia management requires a holistic approach, including psychosocial support. Hair loss is a significant factor affecting the self-esteem of children.

\section{Introduction}

Alopecia areata (AA) is the loss of hair from part of the head. Alopecia totalis (AT) is the hair loss from the entire head, whereas Alopecia Universalis $(A U)$ is losing hair from the whole body. AT/AU is the massive form of AA. AA's pathogenesis is a chronic autoimmune disease of the hair follicles that causes hair loss without scarring. About $7 \%$ of AA patients will develop AT or AU [1]. In population the prevalences of AT, is $0.08 \%, A U 0.03 \%$ [2]. Based on clinical-based study, insidens of AT 3.37\%, AU 0.02\% [2]. Based on the appearance of alopecia symptoms, divided into 2 , namely: (1) Early-onset $<13$ years, and (2) Late-onset $\geq 13$ years. Compared to late-onset, early-onset were more likely to have a family history of AA and atopic dermatitis, nail dystrophy, especially in the AU group [3].

The allergic disease was more found in earlyonset $(45.8 \%)$ than at late-onset $(31.2 \%)$. In AU earlyonset, the prognosis is worse if there is a family history of $A A$ [3].

The purpose of this study was to show that the cause of AT must be sought in as much detail as possible to provide the best therapy and the importance of regular treatment.

\section{Case Presentation}

A 5-year-old boy weighing $13.4 \mathrm{~kg}$ came to the hospital complaining of hair loss all over his head, bald since 2 months before. The eyebrows, eyelashes, and nose hairs were also missing. The diagnosis was AT. The patient was given prosential therapy for 4 months. After 2 months of treatment, hair started to grow slightly, evenly across the head, eyebrows, and eyelashes. After that, the patient was lost contact. Four months later, the patient returned with hair loss complaints again.

The patient's vital signs were normal. Eyes, ENT, heart, lungs, abdomen: normal. Skin: no hair. A series of laboratory examination was performed to find the etiology of AT. Laboratorium: $\mathrm{Hb} 12.1 \mathrm{~g} / \mathrm{dL}$, leukocytes 6480/uL, platelets 324,000/uL, hematocrit $35.5 \%$, Diff Count: basophils $0 \%$, eosinophils $22 \%$, stems $1 \%$, segments $27 \%$, lymphocytes $41 \%$, monocytes $9 \%$. red blood cell 4.29 million/uL, MCV 82.8fL, MCH 28.2pg, MCHC 34.1\%, RDW-CV 11.9\%. Routine feces: normal. Urinalysis was normal. Glucose at $86 \mathrm{mg} / \mathrm{dL}$, total cholesterol $128 \mathrm{~m} / \mathrm{dL}$, triglycerides $46 \mathrm{mg} / \mathrm{dL}$. AST $30 \mathrm{U} / \mathrm{L}$, ALT $11 \mathrm{U} / \mathrm{L}$, total bilirubin $0.41 \mathrm{mg} / \mathrm{dL}$, direct bilirubin $0.13 \mathrm{mg} / \mathrm{dL}$, indirect bilirubin $0.28 \mathrm{mg} / \mathrm{dL}$. Total protein $5.74 \mathrm{~g} / \mathrm{dL}$, albumin $4.33 \mathrm{~g} / \mathrm{dL}$, globulin $1.41 \mathrm{~g} / \mathrm{dL}$. Ureum $21 \mathrm{mg} / \mathrm{dL}$, 
creatinine $0.43 \mathrm{mg} / \mathrm{d}$, uric acid $4.64 \mathrm{mg} / \mathrm{dL}$. Thyroid function: FT4: $1.1 \mathrm{ng} / \mathrm{dL}$ (N: 0.85-1.75), TsHs 0.916 $\mathrm{ulU} / \mathrm{mL}$ (N: 0.70-5.97). The ANA test was negative. Diagnosis: Idiopathic AT with hypereosinophilia. Then, the patient has given Prosential, minoxidil $2 \%$ solution and ointment clobetasol propionate $0.05 \%$.

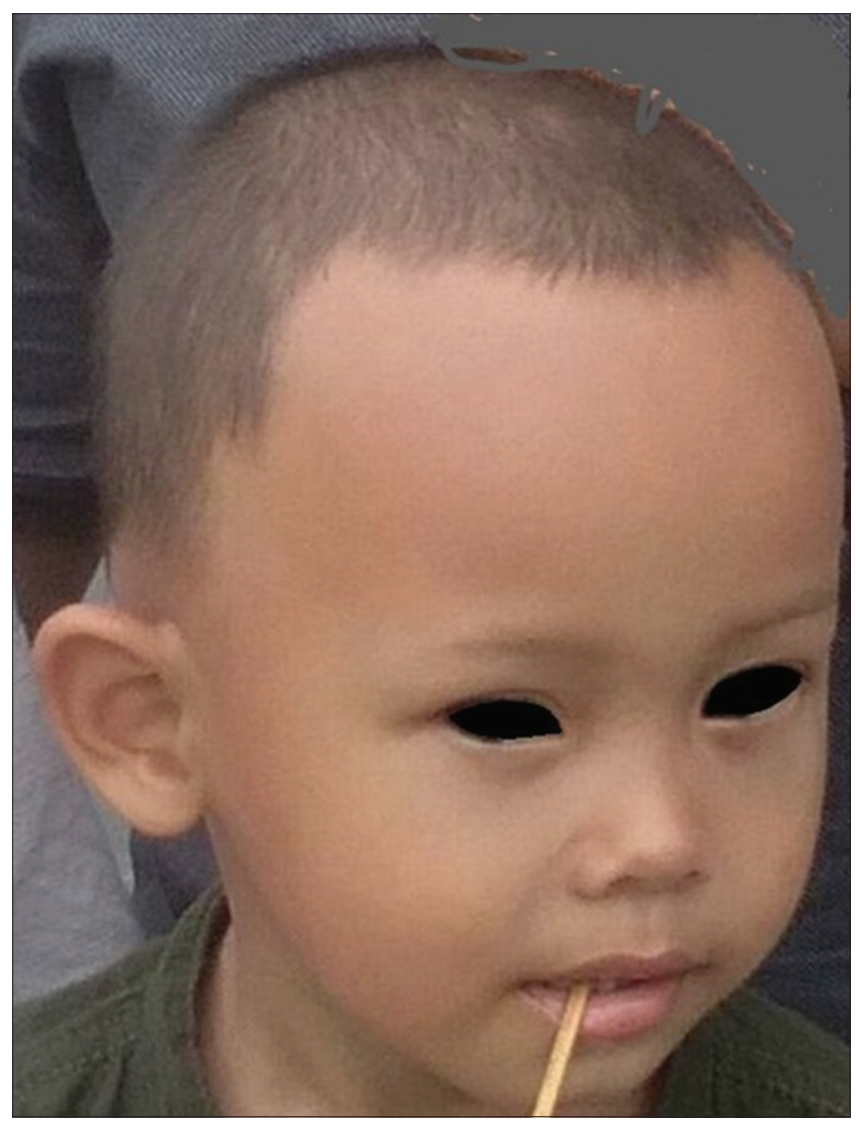

Figure 1: Before alopecia totalis

\section{Discussion}

AT and $A U$ represents the most severe subtypes of AA with more dramatic features and a worse prognosis. Burroway et al. (2020) reported 375 alopecia patients (39 AT, 75 AU, 261 unspecified AT/ $A U)$ followed for at least 5 years. Complete recovery rate (almost all of the head was covered with hair) experienced by AT/AU (32/375) $8.5 \%$, specifically AT $7 / 39(17.9 \%)$ and AU 7/75 (9.3\%) completely healed [4].

The patient experienced gradual hair loss in the 2 months previously. Starting from one part of the back of the head, then to the other part of the head, and in the end, all the head hair fell out, bald. Finally, the lashes, eyebrows, and nose hair are gone. The patient does not feel hair-itching. Because the family could not afford the funds, the supporting examination to look for the etiologic alopecia could not be performed at that time. The diagnosis is AT. The patient treatment is only

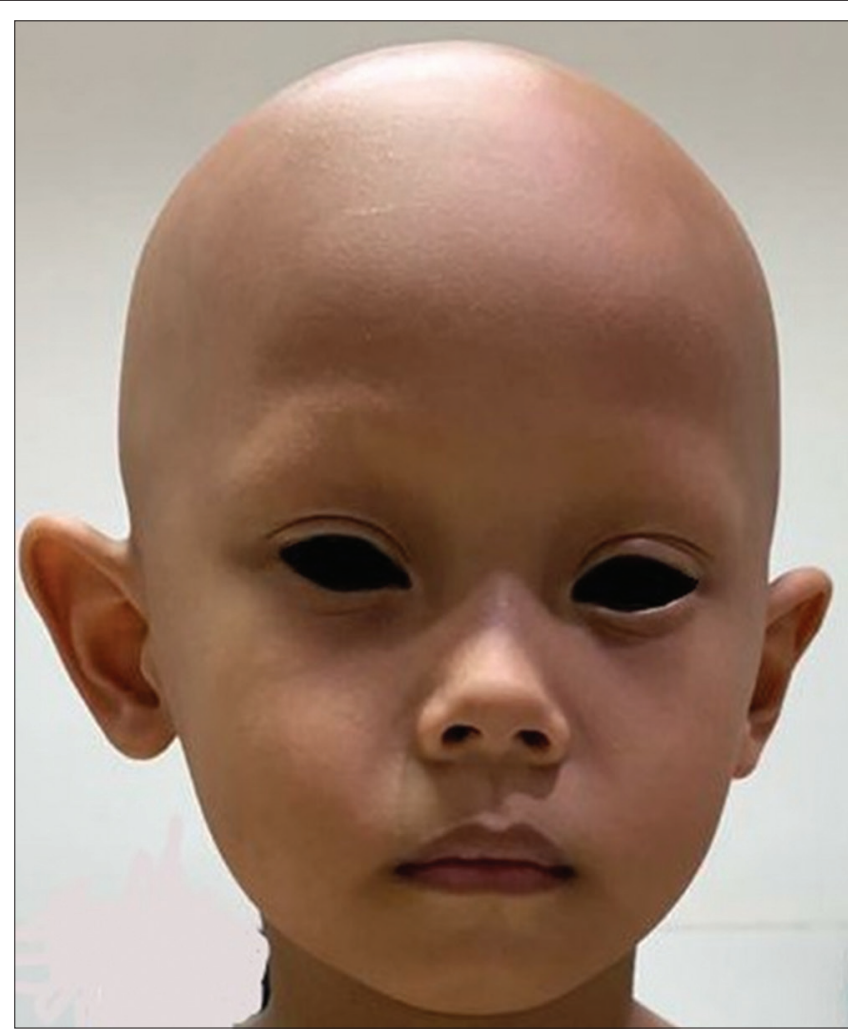

Figure 2: Alopecia totalis

Prosentials. During 2 months of treatment, fine hair began to grow on almost all of the head.

Nevertheless, because they felt the hair would grow back to normal and at no cost, the treatment stopped. Had this patient continued therapy, it was possible to have a complete regrowth. Tosti et al. (2006) reported that 67/69 (97.1\%) AT/AU patients who had undergone a 15-year therapy program ended up discontinuing treatment due to inadequate response to treatment [5]. Jang et al. (2017) reported that 48 of $58(82.8 \%)$ AT/AU patients who did not respond or only partially responded to hair growth ended up stopping treatment [6].

Four months later, the patient came with hair loss complaints all over the head, eyebrows, eyelashes, nose hair. The patient does not complain of hair-itching, and does not pull out his hair, bathes using ordinary soap, not using shampoo. No one in the family has alopecia. The patient's father had bronchial asthma. A series of laboratory examination is performed to find the etiology of AT. In this case, the possibility of pica pulling out and eating hair (trichophagia) can be excluded due to the patient's hemoglobin being normal, not iron deficiency anemia [7].

No scars were found on the scalp, and also did not feel itchy, meaning that it was purely not due to tinea capitis [8]. The patient's hair before and after AT can be seen in Figures 1 and 2, respectively.

On laboratory examination, hypereosinophilia was found, which indicates that the patient has allergies or has a family history of atopy [9]. This hypereosinophilia 
can also be caused by worms. Jiero et al. reveal that the mean eosinophil count correlated significantly with soil-transmitted helminthiasis infection intensity [10]. In this case, the patient had an atopic family history, and the stool examination did not find worms.

Basically, AT is an autoimmune disease. The current understanding is that the condition represents an organ-specific autoimmune disease of the hair follicle with a genetic background. Genome-wide association studies provide evidence for their involvement of both innate and acquired immunity in the pathogenesis, and mechanistic studies in mouse models of $A A$ have specifically implicated an IFN- $\gamma$-driven immune response, including IFN $\gamma$, IFN $\gamma$-induced chemokines, and cytotoxic CD8 T cells as the main drivers of disease pathogenesis [11].

In this patient, the ANA test was negative, so the possibility of SLE and other autoimmune diseases were excluded [12], [13]. Screening practices for thyroid dysfunction in children with AA vary widely among clinicians [13]. Patel et al. reported that out of 298 AA patients (patchy $(68 \%)$, ophiasis $(13 \%)$, totalis $(9 \%)$, Universalis $(10 \%), 59$ patients $(20 \%)$ had abnormal thyroid function test results, with the most common cause being hypothyroid (49\%), Hashimoto's thyroiditis $(41 \%)$ [14]. This patient's thyroid function is normal.

Because the ANA test is negative, the thyroid function is normal, so the cause is not known. The diagnosis is idiopathic AT. Considering that the patient had previously been given Prosential for 2 months and the patient's head had started to grow thin, thin hair all over the head, now the patient is also given prosential therapy. This strategy is suited with what Van Galvan reported that there were $14 \%$ of patients who responded well to the second attempt of treatment with the same therapy regimen [15].

This patient was given a topical clobetasol propionate $0.05 \%$ for $6-14$ weeks, which is widely used and useful in pediatric patients with alopecia [16]. Tosti et al. reported that 28 AT patients were given clobetasol propionate ointment $0.05 \%$ for $6-14$ weeks on the right side of the head by occlusion technique (a plastic sheet is attached over the head that has been given the ointment). Five (17.8\%) patients experienced long-term hair growth. The hair growth only on the head given clobetasol propionate ointment showed that hair growth occurred locally, not systemically [17]. This patient was also given a $2 \%$ minoxidil solution. Wang et al. stated that a $2 \%$ topical minoxidil solution is recommended for children with alopecia to minimize side effects [18].

The atopic family history and the patient's parents' financial limitations will lead to the possibility of failure of the patient's therapy. If there is a case like this, it is necessary to emphasize the prognosis of therapy and the efforts that must be made to maintain long-term treatment to obtain maximum hair regrowth. It should also be emphasized on parents to support psychological strengthening so that patients do not feel inferior in front of friends with normal hair.

\section{Conclusion}

The etiology of AT should be sought in as much detail as possible because alopecia management requires a holistic approach, including psychosocial support. Hair loss is a significant factor affecting the self-esteem of children. Prosential, minoxidil $2 \%$ and clobetasol propionate $0.05 \%$ therapy for hair loss could be considered.

\section{References}

1. Safavi $\mathrm{KH}$, Muller SA, Suman VJ, Moshell AN, Melton LJ. Incidence of alopecia areata in Olmsted County, Minnesota, 1975 through 1989. Mayo Clin Proc. 1995;70(7):628-33. https:// doi.org/10.4065/70.7.628

PMid:7791384

2. Lee $H H$, Gwillim E, Patel KR, Hua T, Rastogi S, Ibler E, et al. Epidemiology of alopecia areata, ophiasis, totalis, and universalis: A systematic review and meta-analysis. J Am Acad Dermatol. 2020;82(3):675-82. https://doi.org/10.1016/j. jaad.2019.08.032

PMid:31437543

3. Cho HH, Jo SJ, Paik SH, Jeon HC, Kim KH, Eun HC, et al Clinical characteristics and prognostic factors in earlyonset alopecia totalis and alopecia universalis. J Korean Med Sci. 2012;27(7):799-802. https://doi.org/10.3346/ jkms.2012.27.7.799

PMid:22787378

4. Burroway B, Griggs J, Tosti A. Alopecia totalis and universalis long-term outcomes: A review. J Eur Acad Dermatol Venereol. 2020;34(4):709-15. https://doi.org/10.1111/jdv.15994 PMid:31593606

5. Tosti A, Bellavista S, lorizzo M. Alopecia areata: A longterm follow-up study of 191 patients. J Am Acad Dermatol. 2006;55:438-41. https://doi.org/10.1016/j.jaad.2006.05.008 PMid:16908349

6. Jang YH, Hong N-S, Moon SY, Eun DH, Lee WK, Chi SG, et al Long-term prognosis of alopecia totalis and alopecia universalis: A longitudinal study with more than 10 years of follow-up: Better than reported. Dermatology. 2017;233:250-6. https://doi. org/10.1159/000477458

PMid:28704810

7. Cannalire G, Conti L, Celoni M, Grassi C, Cella A, Bensi G, et al. Rapunzel syndrome: An infrequent cause of severe iron deficiency anemia and abdominal pain presenting to the pediatric emergency department. BMC Pediatr. 2018;18(1):125. https://doi.org/10.1186/s12887-018-1097-8 PMid:29614986

8. Alexander KC, Kam LH, Kin FL, Benjamin B, Joseph ML. Tinea capitis: An updated review. Recent Pat Inflamm Allergy Drug Discov. 2020;14(1):58-68. https://doi.org/10.2174/18722 $13 \times 14666200106145624$ 


\section{PMid:31906842}

9. Liu FT, Goodarzi H, Chen HY. IgE, mast cells, and eosinophils in atopic dermatitis. Clin Rev Allergy Immunol. 2011;41(3):298-310. https://doi.org/10.1007/s12016-011-8252-4

PMid:21249468

10. Jiero S, Ali M, Pasaribu LS, Pasaribu AP. Correlation between eosinophil count and soil-transmitted helminth infection in children. Asian Pac J Trop Dis. 2015;5(10):813-6. https://doi. org/10.1016/S2222-1808(15)60936-7

11. Trüeb RM, Dias MF. Alopecia areata: A comprehensive review of pathogenesis and management. Clinic Rev Allerg Immunol. 2018;54(1):68-87. https://doi.org/10.1007/s12016-017-8620-9 PMid:28717940

12. Messenger AG, McKillop J, Farrant $P$, McDonagh AJ, Sladden M. British Association of dermatologists' guidelines for the management of alopecia areata 2012. $\mathrm{Br}$ Assoc Dermatol. 2012;166(5):916-26. https://doi. org/10.1111/j.1365-2133.2012.10955.x PMid:22524397

13. Xu L, Liu KX, Senna MM. A practical approach to the diagnosis and management of hair loss in children and adolescents. Front Med. 2017;4:1121. https://doi.org/10.3389/fmed.2017.00112 PMid:28791288
14. Patel D, Li P, Bauer AJ, Castelo-Soccio L. Screening guidelines for thyroid function in children with alopecia areata. JAMA Dermatol. 2017;153(12):1307-10. https://doi.org/10.1001/ jamadermatol.2017.3694

PMid:28973128

15. Vano-Galvan S, Fernandez-Crehuet P, Grimalt R, GarciaHernandez MJ, Rodrigues-Barata R, Arias-Santiago $\mathrm{S}$, et al. Alopecia areata totalis and universalis: A multicenter review of 132 patients in Spain. J Eur Acad Dermatol Venereol. 2017;31(3):550-6. https://doi.org/10.1111/jdv.13959 PMid:27608049

16. Fernando T, Goldman RD. Corticosteroids for alopecia areata in children. Can Fam Physician. 2020;66(7):499-501. PMid:32675094

17. Tosti A, Piraccini BM, Pazzaglia M, Vincenzi C. Clobetaso propionate $0.05 \%$ under occlusion in the treatment of alopecia totalis/universalis. J Am Acad Dermatol. 2003;49(1):96-8. https://doi.org/10.1067/mjd.2003.423

PMid: 12833016

18. Wang E, Lee JS, Tang M. Current treatment strategies in pediatric alopecia areata. Indian J Dermatol. 2012;57(6):459-65. https://doi.org/10.4103/0019-5154.103066

PMid:23248364 